\title{
ISOLASI DAN IDENTIFIKASI BAKTERI ASAM LAKTAT (BAL) DARI BUAH MANGGA (Mangifera indica L.)
}

\author{
Fila Delvia*, Aditya Fridayanti, Arsyik Ibrahim \\ Laboratorium Penelitian dan Pengembangan Kefarmasian "Farmaka Tropis", \\ Fakultas Farmasi, Universitas Mulawarman, Samarinda \\ *Email : ila.liing@yahoo.co.id
}

\begin{abstract}
The research has been done for the isolation and identification of lactic acid bacteria (LAB) from mango (Mangifera indica L.). This research aimed to obtain isolate of lactic acid bacteria that is in mango (Mangifera indica L.) and determine the characteristics of lactic acid bacteria isolate (LAB) of mango (Mangifera indica L.). The method used is spoiled technique of mango (Mangifera indica L.) and isolation using selective media MRS Broth and MRS Agar. The identification isolate of lactic acid bacteria (LAB) used methods macroscopically and microscopically with indirect coloring, gram staining and used biochemical with katalase testing. The results obtained in the form of characteristic isolate of lactic acid bacteria displayed form of bacteria with circle, smooth surface, curve, entire side and white. The microscopically displayed stick form of bacteria and purple with gram coloring.
\end{abstract}

Key word: Mangifera indica L., Lactic Acid Bacteria , Spoiled, Isolation, Identification

\begin{abstract}
ABSTRAK
Telah dilakukan penelitian mengenai isolasi dan identifikasi bakteri asam laktat (BAL) dari buah mangga (Mangifera indica L.). Penelitian ini bertujuan untuk memperoleh isolat bakteri asam laktat yang ada di dalam buah mangga (Mangifera indica L.) dan mengetahui karakteristik isolat bakteri asam laktat (BAL) dari buah mangga (Mangifera indica L.). Metode yang digunakan yaitu teknik pembusukan buah mangga (Mangifera indica L.) dan isolasi dengan menggunakan media selektif MRS Broth dan MRS Agar. Di identifikasi isolat bakteri asam laktat (BAL) secara makroskopik dan mikroskopik dengan pewarnaan tak langsung dan pewarnaan gram serta secara biokimia dengan uji katalase. Hasil yang di peroleh berupa karakteristik isolat bakteri asam laktat yang memperlihatkan bentuk bakteri bulat dengan permukaan halus, elevasi cembung, tepi entire dan berwarna putih
\end{abstract}


susu dan dari pengamatan mikroskopik memperlihatkan bentuk bakteri batang dan berwarna ungu dengan pewarnaan gram.

Kata kunci:Mangifera indica L., Bakteri Asam Laktat, Pembusukan, Isolasi,
Identifikasi

\section{PENDAHULUAN}

Bakteri asam laktat adalah bakteri yang memiliki kontribusi yang besar dalam dunia pangan. Bakteri asam laktat selain biasanya digunakan sebagai pangan fungsional juga sering digunakan sebagai pengawet alami dari suatu produk pangan fermentasi. Penggunaan bakteri asam laktat sebagai pengawet alami dengan metode biopreservatif telah banyak dikembangkan dengan menggunakan bakteri asam laktat secara langsung atau menggunakan metabolitnya sebagai agen antimikroba.

Penggunaan BAL ini dikarenakan bakteri asam laktat disebut sebagai food grade microorganisms yang merupakan mikroba yang tidak beresiko terhadap kesehatan karena tidak menghasilkan racun berbahaya pada bahan pangan melainkan mempunyai fungsi sebaliknya yang baik bagi kesehatan. Hal ini karena bakteri asam laktat dapat menghambat secara alami mikroba patogen [1].

Beberapa metabolit aktif yang dihasilkan oleh bakteri asam laktat yaitu asam laktat, etanol, hidroperoksida dan bakteriosin. Metabolit yang dihasilkan oleh bakteri tersebut merupakan agen yang dapat digunakan dalam membunuh bakteri. Salah satu yang digunakan sebagai antimikroba yaitu bakteriosin yang merupakan suatu senyawa peptida. Dilaporkan bahwa bakteriosin memegang peranan paling penting dalam menanggulangi infeksi akibat mikroorganisme [2]. Selain itu asam laktat yang di produksi oleh BAL dapat menurunkan $\mathrm{pH}$ lingkungan. $\mathrm{pH}$ yang rendah dapat menghambat kontaminasi mikroba pembusuk dan juga membunuh mikroba patogen terutama yang ada didalam tubuh.

Penelitian tentang isolasi BAL telah banyak dilakukan terutama pada produk-produk daging mentah ataupun kalengan, produk susu (yoghurt, keju, dadih), fermentasi (tape, tempe, beer). Namun belum begitu banyak yang diisolasi dari buah-buahan dan sayur-sayuran tropis. Beberapa sumber memaparkan bahwa pada buah-buahan dan sayuran seperti durian, nenas, sirsak, cacao, pisang, mangga, tomat, kubis, asinan sawi, selada, kacang panjang dan lain sebagainya adalah potensial sebagai sumber BAL [3].

Kalimantan terkenal dengan produksi buah mangga yang berlimpah. Beberapa jenis mangga dapat ditemui disini. Dilaporkan bahwa di Kalimantan terdapat 31 jenis Mangifera dan 3 jenis diantaranya adalah endemik. Dilaporkan bahwa di Kalimantan ditemukan 23 jenis Mangifera yang merupakan tumbuhan asli dan 4 jenis yang merupakan tumbuhan endemik. Sehingga dapat dikatakan bahwa Kalimantan merupakan pusat persebaran jenis-jenis mangga (Mangifera spp.) [4].

Berdasarkan kemungkinan adanya bakteri asam laktat yang tumbuh pada buah mangga (Mangifera indica L.) dan besarnya manfaat yang dihasilkan dari bakteri asam laktat. Maka akan dilakukan penelitian untuk mengisolasi bakteri 
asam laktat dari buah mangga (Mangifera indica L.) serta mengidentifikasi karakteristik bakteri tersebut.

\section{METODE PENELITIAN}

\section{Bahan}

Penelitian ini menggunakan objek penelitian yaitu buah mangga matang dengan jenis mangga yang diteliti yaitu mangga kuweni (Mangifera odorata). Bagian yang akan diteliti adalah buah mangga kuweni masak yang telah menimbulkan aroma khas dan tidak cacat yang diperoleh dari desa Sekolaq Darat Kubar, medium de Men Rogrosa Sharpe (MRS) agar oxoid dan medium de Men Rogrosa Sharpe (MRS) broth oxoid, pepton water, medium potato dektrosa agar (PDA) dan Nutrient Agar Merck, $\mathrm{NaCl} 0,9 \%$, larutan $\mathrm{H}_{2} \mathrm{O}_{2}$, cat kristal violet, cat lugol iodin, alcohol $96 \%$ dan safranin yang diperoleh dari laboratorium Farmasi Unmul.

\section{Peralatan}

Alat yang digunakan dalam penelitian ini yaitu toples, cutter, timbangan analitik, labu ukur, labu Erlenmeyer, cawan petri, incubator, laminar air flow, autoklaf, kaca objek, hot plate, spoit, pinset, bunsen, cawan porselin, spatel logam, ose bulat, rak tabung, botol vial, botol semprot, mikroskop electron.

\section{Prosedur}

\section{Penyiapan Sampel}

Sampel buah mangga diambil di daerah Sekolaq Darat Kubar. Buah mangga merupakan buah mangga masak dan tidak cacat, dicuci dengan air mengalir dan dikeringkan. Setelah kering dikupas kulitnya dengan pisau steril.

\section{Proses pembusukan}

Sampel buah mangga yang telah dikupas dan dipotong dimasukkan ke dalam daun pisang dan dibungkus. Setelah dibungkus dimasukkan ke dalam wadah berupa toples kedap udara dan cahaya. Dilakukan pembusukan selama 72 jam pada suhu ruangan.

\section{Pengenceran Sampel}

Sampel hasil pembusukan di ambil pulpnya, dicampurkan lalu dimasukkan sebanyak 1 gram ke dalam tabung reaksi yang berisikan $9 \mathrm{~mL}$ MRS broth. Setelah dimasukkan di inkubasi selama 48 jam pada suhu $37^{\circ} \mathrm{C}$. Kemudian hasil inkubasi diambil dan dilakukan pengenceran dengan mengambil $100 \mu \mathrm{L}$ hasil inkubasi ditambahkan ke dalam $900 \mu \mathrm{L}$ pepton water sehingga diperoleh pengenceran $10^{-1}$. Kemudian hasil dari pengenceran $10^{-1}$ diambil kembali $100 \mu \mathrm{L}$ dan dimasukkan kembali ke dalam tabung berisi pepton water $900 \mu \mathrm{L}$. Pengenceran terus dilakukan sampai didapat pengencean $10^{-9}$. 


\section{Isolasi bakteri asam laktat (BAL)}

Pengenceran $10^{-9}$ yang diperoleh diambil dengan menggunakan ose bulat sebanyak 1 ose. Kemudian dilakukan inokulasi ke dalam medium MRS agar dengan membagi cawan Petri ke dalam empat kuadran yaitu kuadran 1, kuadran 2, kuadran 3 dan kuadran 4 dilakukan metode gores membentuk zig zag bersambung tiap kuadran. Diinkubasi cawan petri selama 7 hari pada suhu $37^{\circ} \mathrm{C}$. Setelah proses inkubasi selesai dilanjutkan dengan mengisolasi koloni-koloni yang tumbuh masing-masing berdasarkan perbedaan penampakan yang ada didalam cawan Petri tiap kuadran. Dilakukan isolasi sampai diperoleh isolat atau koloni tunggal dari tiap cawan Petri.

\section{Identifikasi bakteri asam laktat}

Isolat yang diperoleh diidentifikasi menggunakan uji katalase dan metode makroskopik serta mikroskopik. Uji katalase dengan meneteskan larutan $\mathrm{H}_{2} \mathrm{O}_{2}$ pada objek glass, kemudian diambil olesan bakteri dengan menggunakan ose dan dioleskan pada larutan pada objek glass, dilihat reaksi yang terbentuk jika tidak terbentuk gelembung menandakan reaksi positif. Metode makroskopik dengan melihat langsung isolat bakteri yang tumbuh pada medium meliputi bentuk dan warna bakteri. Dan metode mikroskopik dengan menggunakan mikroskop dengan metode pewarnaan gram. Sedangkan pewarnaan gram dilakukan dengan mengoleskan bakteri diatas objek glass, difikasasi lalu ditetesi cat gram A, diamkan selama 1 menit, ditetesi cat gram B, diamkan selama 1 menit, ditetesi cat gram $\mathrm{C}$, diamkan selama 30 detik, ditetesi cat gram D, diamkan 2 menit. Kemudian ditutup dengan cover glass dan ditetesi dengan minyak emersi lalu diamati bentuk dan warna sel.

\section{HASIL DAN PEMBAHASAN}

\section{Isolasi bakteri asam laktat (BAL)}

Isolasi bakteri merupakan sebuah teknik untuk mendapatkan koloni tunggal suatu bakteri. Isolasi bakteri asam laktat melalui proses pembusukan untuk mendapatkan bakteri asam laktat dan dengan menggunakan media selektif de Men Rogrosa Sharpe yang bertujuan mengoptimalkan pertumbuhan dan mendapatkan koloni bakteri asam laktat yang diharapkan.

Proses isolasi dilakukan proses plating, kultur dari pengenceran $10^{-9}$ diinokulasikan pada media MRS Agar dengan metode gores dengan dibagi dalam empat kuadran dan diinkubasi dalam inkubator. Koloni BAL tunggal yang tumbuh dimurnikan kembali dengan cara menginokulasikan kembali koloni ke dalam media MRS Agar (Merck) secara gores dan diinkubasi pada suhu selama $37^{\circ} \mathrm{C} 48$ jam dalam suasana anaerob [5]. 


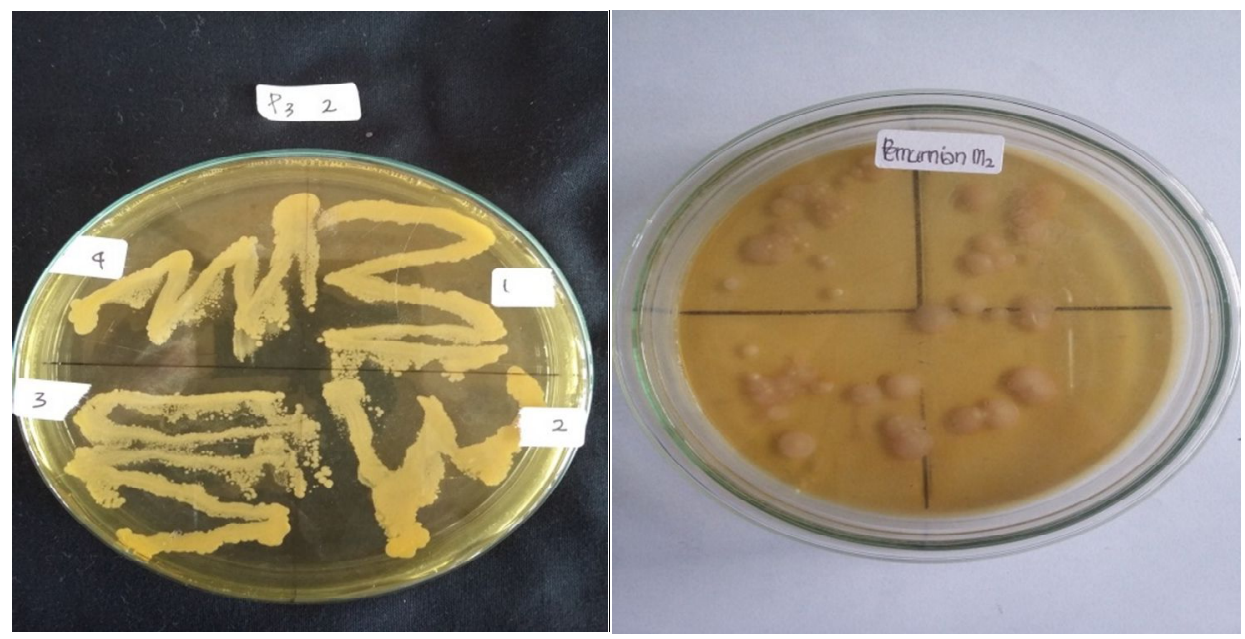

Gambar 1. Hasil isolasi pada media MRS agar

Dari hasil isolasi yang dilakukan diperoleh koloni tunggal dari buah mangga kuweni yang disebut sebagai isolat sebanyak satu isolat yang memiliki bentuk dan warna yang sama dimasing-masing kuadran.

\section{Identifikasi Isolat Hasil Isolasi}

Identifikasi bakteri bertujuan untuk menentukan karakteristik khusus yang dimiliki oleh isolat yang diperoleh yang mempunyai karakteristik sama dengan bakteri yang diinginkan. Beberapa cara yang digunakan untuk mengidentifikasi BAL pada penelitian ini yaitu dilakukan secara makroskopik, mikroskopik dan uji katalase.

a. Identifikasi Makroskopik

Identifikasi makroskopik dilakukan dengan melihat langsung isolat yang tumbuh pada media agar meliputi warna, bentuk, tepi, permukaan serta elevasi yang terbentuk pada isolat.

Tabel 1. Identifikasi Isolat secara Makroskopik

\begin{tabular}{ccccccc}
\hline No. & Isolat & Warna & Bentuk & Tepi & Permukaan & Elevasi \\
\hline 1. & $\mathrm{M}_{1}$ & Putih susu & Bulat & Entire & $\begin{array}{c}\text { Halus } \\
\text { mengkilap }\end{array}$ & Cembung \\
\hline
\end{tabular}

Dari hasil identifikasi secara makroskopik memperlihatkan hasil berupa isolat yang mempunyai warna putih susu, bentuk bulat, tepi entire, permukaan halus dan elevasi yang cembung. Hasil ini sesuai dengan penelitian yang dilakukan sebelumnya [1] dengan sampel buah mangga yang menunjukkan penampakan secara makroskopik yang sama dengan hasil yang diperoleh pada penelitian ini. 


\section{b. Identifikasi Mikroskopik}

Identifikasi secara mikroskopik dilakukan dengan menggunakan mikroskop untuk melihat bentuk dari sel bakteri. Identifikasi bakteri asam laktat secara mikroskopik dilakukan dengan menggunakan pewarnaan tidak langsung dan pewarnaan gram.

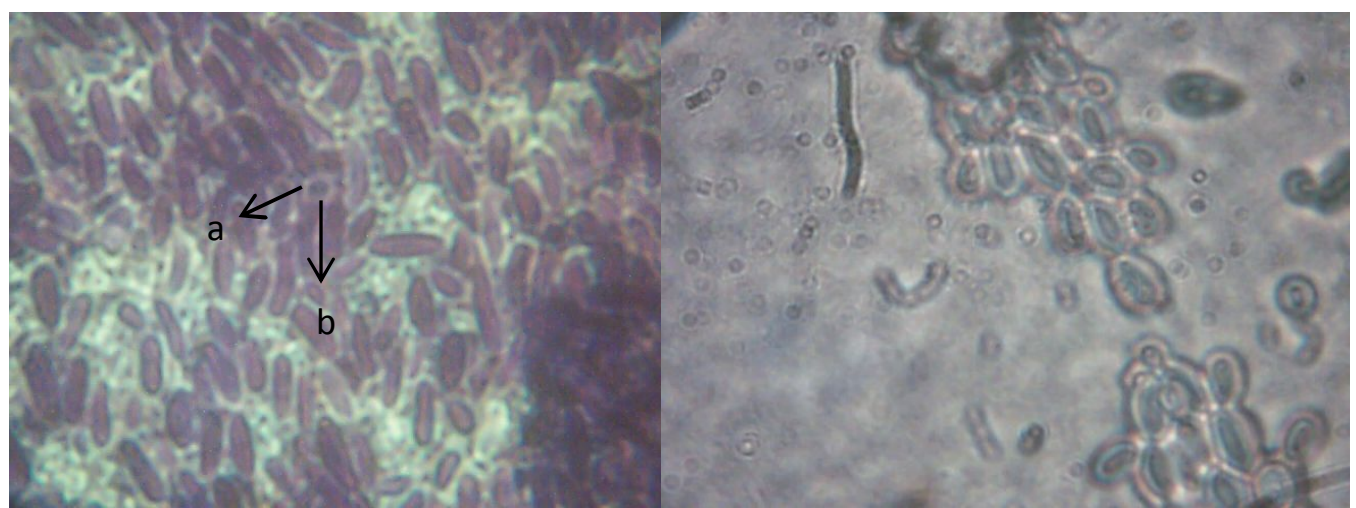

Gambar 2. Identifikasi pewarnaan tak langsung dan gram secara Mikroskopik dengan perbesaran $100 \mathrm{x}$

Pengamatan pada mikroskop dengan pewarnaan gram menunjukkan hasil pengujian bahwa sel bakteri berwarna ungu dengan pengujian gram. Hal ini dikarenakan bakteri asam laktat termasuk dalam golongan bakteri gram positif [4]. Dimana bakteri gram positif mempunyai ciri dinding sel dengan peptidoglikon yang lebih tebal sehingga penyerapan warna dari cat kristal violet yang terserap dalam sel akan bertahan walaupun dilakukan pencucian menggunakan larutan alkohol yang diharapkan dapat melunturkan cat warna yang ada sebelumnya. Dengan bertahannya cat warna kristal violet yang berwarna ungu ini didalam sel bakteri maka cat warna berikutnya tidak akan bisa terserap lagi. Sehingga warna sel akan tetap berwarna seperti warna cat yang dipakai pertama kali. Pengamatan secara mikroskopik tidak langsung menunjukkan hasil berupa bentuk sel dari isolat bakteri yaitu berbentuk batang dengan dinding sel (a) dan selubung sel (b) serta bentuk sel yang bergerombol membentuk rantai antara satu sel dengan sel yang lainnya.

\section{c. Identifikasi Uji Katalase}

Pengujian katalase adalah pengujian secara biokimiawi yang memperlihatkan aktivitas dari bakteri yang menghasilkan enzim katalase ditandai dengan terbentuknya gelembung pada pengujian yang menandakan reaksi positif. 


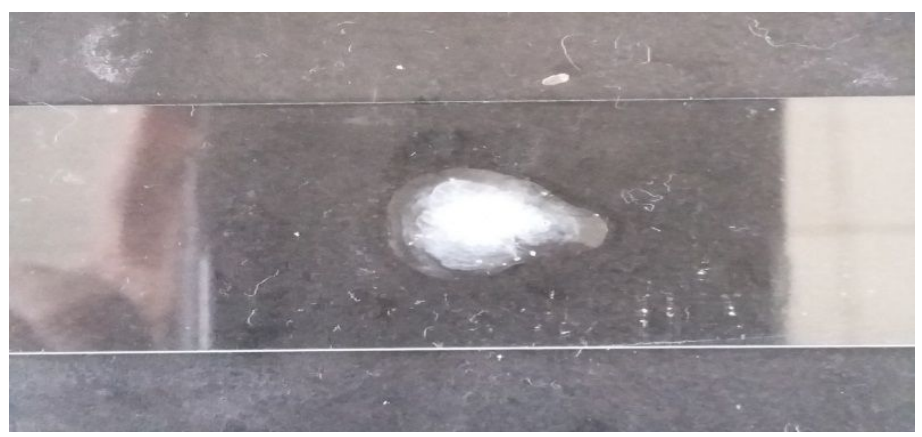

Gambar 3. Hasil uji katalase

Uji katalase menunjukkan bahwa isolat bakteri yang diuji menunjukkan hasil berupa katalase negatif dimana tidak terbentuknya gelembung pada object glass yang terdapat cairan $\mathrm{H}_{2} \mathrm{O}_{2}$ saat diolesi dengan bakteri. Hal ini dikarenakan bakteri asam laktat tidak memproduksi enzim katalase yang dapat mengubah hidrogen peroksida menjadi air dan oksigen dan berkaitan dengan kemampuan bakteri asam laktat yang hanya membutuhkan sedikit oksigen untuk dapat hidup.

\section{KESIMPULAN}

1. Isolat bakteri asam laktat dari buah mangga mempunyai karakteristik secara makroskopik yaitu warna putih susu, bentuk bulat, tepi entire, permukaan halus dan elevasi cembung.

2. Hasil identifikasi bakteri asam laktat dari buah mangga menunjukkan hasil reaksi negative terhadap uji katalase dan merupakan bakteri gram positif

\section{DAFTAR PUSTAKA}

[1] Fitriyani, Ida. 2010. Isolasi, Karakterisasi, Identifikasi Bakteri Asam Laktat (BAL) dari Buah Mangga Matang Yang Berpotensi Menghasilkan Antimikroba.Skripsi. UIN Sunan Kalijaga. Yogyakarta.

[2] Lawalata, Helen, J, dkk. 2010. Bakteri Asam Laktat Pada Bakasang dan Aktivitas Penghambatannya Terhadap Bakteri Patogen dan Pembusuk. Seminar Nasional Biologi Fakultas Biologi UGM. Yogyakarta.

[3] Oakey, L, et al. 2000. Antimicrobial Peptide Alternative to Antibiotics. Institute Technology Tallaght.

[4] Nuryady, Moh, Mirza, dkk. 2013. Isolasi dan Identifikasi Bakteri Asam Laktat Asal Youghurt. UNEJ JURNAL I (5): 1-11.

[5] Sari, Maya, N, Y, dkk. 2013. Isolasi, Karakterisasi, dan Identifikasi DNA Bakteri Asam Laktat (BAL) Yang Berpotensi Sebagai Antimikroba dari Fermentasi Markisa Kuning (Passiflora edulis var. flavicarpa). Jurnal Kimia Unand (ISSN No. 2303-3401), Volume 2 Nomor 2. 